\title{
Bank Privatization in MENA and OECD Countries and the Role of Economic, Political and Institutional Factors
}

\author{
Anis Ochi ${ }^{1}$, Samir Maktouf ${ }^{1} \&$ Makram Nouaili $^{2}$ \\ ${ }^{1}$ Faculty of Economic Sciences and Management of Tunis, University of Tunis El Manar, Tunisia \\ ${ }^{2}$ School Higher Institute of Management, Gabes University, Tunisia \\ Correspondence: Anis Ochi, Faculty of Economic Sciences and Management of Tunis, University of Tunis El \\ Manar, Tunisia. Tel: 216-55-788-438. E-mail: ochi.anis@live.fr \\ Received: February 15, 2015 \\ Accepted: March 11, 2015 \\ Online Published: March 25, 2015 \\ doi:10.5539/ibr.v8n4p291 \\ URL: http://dx.doi.org/10.5539/ibr.v8n4p291
}

\begin{abstract}
We investigate how political, economic and institutional factors are related to a country's decision to privatize state-owned banks. Using a panel of 38 OECD and MENA countries from 1988 to 2011, we find that political and institutional factors significantly affect the likelihood of bank privatization only in developing countries. Specifically, in MENA countries, bank privatization is more likely the more accountable the government is to its people. In contrast, none of our political variables affects the bank privatization decision in OECD countries except the ideological orientation of government. Economic factors (such as the quality of the nation's banking sector) are significant determinants of bank privatization in both MENA and OECD nations.
\end{abstract}

Keywords: privatization, logistic regression, duration models, bank

\section{Introduction}

The state considers the banking system as a vital sector that plays an important role in the functioning of the economy. Public banks often provide to government policy tools and important instruments for implement its programs. Therefore, the privatization of the banking sector is often seen as a sensitive issue.

From the 1980s, privatization has inspired a vast empirical literature and became a field search implemented. Several previous studies suggest that privatization increases government revenues, contribute to development of the capital market and generally improves the efficiency of the bank because the problems of corporate governance may be more severe for public companies. To our knowledge, few studies have examined the factors that influence privatization decisions and have focused on the determinants of this phenomenon

However, the government's decision to sell the state-owned banks requires not only the financial considerations but also the costs and benefits policies. The benefits of privatization are the improvement of state revenues, the development of financial markets and efficiency gains. While, the costs of privatization are more nuanced, they include loss of the ability of the government to use the bank for political reasons, layoffs of surplus workers and the loss of private benefits to politicians.

The objective of this paper is to answer the following questions: Why governments privatize public banks? How economic, political and institutional factors affect the timing of bank privatizations? Furthermore, we partition the sample into OECD and MENA countries to see if there are systematic differences based on level of economic development.

The remainder of the paper is organized as follows: section 2 provides a review of the related literature. Our estimation method is reported in Section 3. Section 4 presents the data and variables. Section 5 presents our empirical results. The paper's concluding remarks are provided in Section 6.

\section{Literature Review}

Several empirical and academic studies have investigated the privatization of the banking sector through the use of econometric techniques. The majority of these studies examine the impact of privatization on the performance of the banking sector. But rare among them analyzing the relationship between institutional, economic and political factors in developed and developing countries and their decisions to privatize public banks.

Beginning with the work of Boehmer et al. (2005) who have used a panel of 101 countries from 1982 to 2000, 
they found that political factors significantly affect the likelihood of bank privatization only in developing countries. Specifically, in non-OECD countries, bank privatization is more likely the more accountable the government is to its people. In contrast, none of their political variables affects the bank privatization decision in developed countries. Economic factors (such as the quality of the nation's banking sector) are significant determinants of bank privatization in both OECD and non-OECD nations.

Bortolotti et al. (2001) through their analysis of the privatization process in 49 countries during the period 1977-1996, they showed that the privatization decision and the choice of the method of privatization seem beings influenced by the political majority in power and fiscal constraints in the public sector, while the success of privatization in terms of turnover requires appropriate legal institutions and developed capital markets.

Clarke and Cull (2002) examined the political economy of bank privatization in Argentina in the wake of institutional changes related to the implementation of the convertibility plan and the tequila crisis. Their empirical results strongly support the hypothesis that political incentives affect the likelihood of privatization. They found that poorly performing banks were more likely to be privatized, while the big banks were less likely to be privatized. They also found that high levels of unemployment and large proportions of public sector employees reduce the likelihood of privatization.

On the other hand, Bortolotti and Pinotti (2003) used a panel of 21 countries, they found that political and legal factors significantly affect the decision of public bank privatization. Also, they conclude that the likelihood of bank privatization is significantly associated with the characteristics of a country's political system.

Bortolotti, Fantini and Siniscalco (2003) used a panel of 34 developing and developed countries from 1977 to 1999, they affirmed that privatization policies are an important source for governments who consider them very often as a strategic sector to finance its budget deficits. Also, they found that governments use the privatizations to promote the development of their financial markets. Finally, they showed that privatization requires the appropriate legal and political institutions.

With the aim of measure the effect of political and economic factors on the likelihood of privatization, Clarke and Cull (2005) studied the role and the quality of the domestic banking sector, the fiscal and the trade unions on the decisions of bank privatization in Argentina. They found that most decisions of bank privatization in Argentina. They found that most privatization decisions are affected by political considerations. It therefore seems that political factors are important determinants of privatization of public banks in Argentina.

Recently, Mary Simon (2009) points out that "the British budget deficit inflated by bank rescue plans and stimulus measures adopted in response to the crisis is expected to reach 175 billion pounds in 2010, approximately $12.4 \%$ of GDP, according to government projections. To reduce some of the public deficit of the United Kingdom, the government wants to sell a series of assets between 2011 and 2014 with a total of $€ 17$ billion. In conclusion, the institutional factors on the one hand, the development of capital market, budget deficits and banking crises as economic factors on the other hand are important determinants that affect the likelihood of bank privatization.

\section{Econometric Methodology}

Our main objective is to present the methodology us to study the determinants of a country's decision to privatize a state-owned banks and the timing of this decision. We also ask how these determinants differ between developing (MENA) and developed (OECD) countries.

First, we present an univariate comparison of the country characteristics during the year of the bank privatization. Then we will use a logistic regression model to evaluate the marginal effects of each variable on the probability of a bank privatization. Then, we estimate a duration model with time-varying covariates. This allows us to examine the time it takes a country to privatize a public bank after its first decision to privatize any enterprise. Finally, we will examine the factors influencing the decision of the state-owned banks in each country of our sample.

The unconditional analysis is interesting because it gives us a whole view of potential determinants. It also allows us to identify the equilibrium changes associated with the decision to privatize a bank. However, without a multivariate analysis, we cannot disentangle the relative influence of each variable. To this end, we model the annual probability that a country privatizes a bank. By construction, the logistic analysis is not able to explicitly incorporate the dimension of time. The decision of country to privatize a bank is likely to change over time, such as changing of economic, financial, political and institutional conditions. We model this time dependence using duration models. We will measure the time between the first-ever privatization of a country and its first operation to privatize a state-owned banks. Thereafter, we will examine the factors that determine the duration of this 
period. Finally, since the first bank privatization of a country may be occasional, we complete our analysis by studying the decision of the privatization of state-owned banks in each country.

For each regression, we report maximum-likelihood coefficient estimates and the p-value of the associated Wald $\mathrm{X} 2$ statistics. In addition, to aid interpretation of the estimates, we compute the odds ratios (the change in the probability of a bank privatization) for a one-standard-deviation increase in each independent variable. Finally, we provide the $\mathrm{p}$-value of a likelihood-ratio test that all coefficients are jointly equal to zero to gauge the explanatory power of each regression. An advantage of our data panel is that we can pinpoint each country's first privatization, which we deem the start of a privatization program.

When a government privatized its first bank, the natural question that arises is the length of time of this process. The general decision to start the privatization of state-owned enterprises differs from the decision to privatize a state-owned bank claimed political considerations. To estimate the determinants of the length of this process, we will use the hazard-rate duration model. We suppose that a country's probability of exiting in each period is given by the following hazard rate:

$$
h(t)=(\text { probability of exiting between } t \text { and } t+\Delta t) /(\text { probability of exiting after } t)
$$

We will use the semi-parametric estimation Cox (1972) model: $h(t, X)=h_{0}(t) e^{X(t) \beta}$

Where $h_{0}(t)$ : is the baseline hazard function represents the value when all covariates are null. This baseline hazard is left unspecified as in the Cox (1972) model. $X(t)=\left(X_{1}, \ldots, X_{n}\right)^{\prime}$ represents the vector of covariate values. $X_{1} \ldots, X_{n}$ represent the economic, political and institutional factors that have a multiplicative effect on the hazard $\beta=\left(\beta_{1}, \ldots, \beta_{\mathrm{n}}\right)^{\prime}$ represents vector of parameters (coefficients) which are estimated via partial maximum likelihood.

$$
\beta^{\prime} X=\beta_{1} X_{1}+\ldots+\beta_{n} X_{n}
$$

The matrix of covariates $X$ consists of the same explanatory variables used in the logistic regression.

Among the classical forms of links (log-linear model, linear model, logistic model), we will adopt that of the logistics form. As in the regression of this form, we will consider the various countries in our sample have a choice between the privatization of state-owned banks or keep them under state ownership. However, we will model this decision a dynamic way in enabling countries to revisit the decision of each year until a bank is sold or our sample period terminates. However, this case represents a model of random right-censoring (conditional to $\mathrm{X}$ ), because a country that has not yet privatized a bank the end of our sample period may still do so in the future. The duration model can explicitly incorporate censored observations.

A logit model seems to be best adopted to investigate the impact of explanatory variables on the likelihood of privatization (the government's decision to privatize a state-owned bank). The values calculated by logistic regression give us the probability of privatization. If an exogenous variable positively correlated with the endogenous variable, this means that the increase in the explanatory variable increases the triggering probability of privatization. We will apply the automated stepwise logistic regression allows us to keep only the best predictors of all the explanatory variables included in our model.

The dependent variable $\mathrm{P}$ is a dichotomous variable (ie a variable dammy d) which is equal to 1 if at least one operation of bank privatization has been completed and 0 otherwise.

$$
\begin{aligned}
& P R I V=1 \text { if } P R I V^{*}>0 \\
& P R I V=0 \text { if otherwise }
\end{aligned}
$$

\section{The Data and Variables}

Our empirical study focuses on the study of the impact of economic, political and institutional factors on the government's decision to privatize a public bank. To do this, we selected a sample of 38 developed and developing countries over the period 1988 to 2011: 16 MENA countries namely: Egypt, Tunisia, Algeria, Morocco, Libya, Jordan, Lebanon, Saudi Arabia, Bahrain, Oman, Kuwait, Qatar, the United Arab Emirates, Yemen Iran and Israel, and 22 OECD countries namely Germany, Australia, Austria, Belgium, Denmark, Spain, Finland, France, Greece, Iceland, Ireland, Italy, Japan, Luxembourg, Norway, New Zealand, the Netherlands, Portugal, the United Kingdom, Sweden, Switzerland and Turkey.

In the following table, we present the main economic, political and institutional variables that can influence the policy of privatization with its resources: 
Table 1. Variables and sources

\begin{tabular}{|c|c|}
\hline Variable & Resource \\
\hline $\begin{array}{l}\text { Gross National Income (GNI) per capita = PPP-adjusted (current } \\
\text { international \$) }\end{array}$ & Database of the World Bank. \\
\hline $\begin{array}{l}\text { Gross Domestic Product }(\mathrm{GDP})=\text { in millions of current, local } \\
\text { currency }\end{array}$ & Database of the World Bank. \\
\hline $\begin{array}{l}\text { Budget deficit }(\mathrm{BD})=\text { Government Deficit in millions of units of } \\
\text { local currency }\end{array}$ & $\begin{array}{l}\text { Central Intelligence Agency (World Factbook). OECD Factbook. } \\
\text { Global Finance (Hrvard Business School). } \\
\text { Statistiques Financières Internationales. }\end{array}$ \\
\hline $\begin{array}{l}\text { Market Capitalization (MC) = Total Equity Market Capitalization - } \\
\text { in millions of current \$ }\end{array}$ & $\begin{array}{l}\text { Emerging Stock Markets Factbook } \\
\text { Base de données de la banque mondiale. } \\
\text { COSOB (Bourse d'Alger) et Libyan Stock Market (Site officiel). }\end{array}$ \\
\hline Debt Crisis $(\mathrm{DC})=1$ if country experienced debet crisis that year & $\begin{array}{l}\text { Luc Laeven and Fabian Valencia (2008) } \\
\text { IMF working paper WP/08/224 }\end{array}$ \\
\hline Non-performing loan $(\mathrm{NPL})=$ as a percentage of total bank loans & $\begin{array}{l}\text { World Development Indicators (WDI). } \\
\text { World Bank and the various reports of the IMF } \\
\text { The central banks of each country. }\end{array}$ \\
\hline $\begin{array}{l}\text { Corruption Index }(\mathrm{CI})=\text { Measure of overall corruption; Lower = } \\
\text { greater corruption }\end{array}$ & $\begin{array}{l}\text { Transparency International. } \\
\text { International Country Risk Guide, PRS Group }\end{array}$ \\
\hline $\begin{array}{l}\text { Size of private banking sector }(\mathrm{SPBS})=\text { Loans by private banks to } \\
\text { private sector; millions of units of local currency }\end{array}$ & International Financial Statistics \\
\hline $\begin{array}{l}\text { Government Stability }(\mathrm{GS})=\text { Measure of overall government } \\
\text { stability; High = greater government stability }\end{array}$ & International Country Risk Guide, PRS Group. \\
\hline $\begin{array}{l}\text { Government Effectiveness (GS) = Measure of overall government } \\
\text { effectiveness; High = greater government effectiveness }\end{array}$ & Worldwide Governance Indicators, The World Bank Group. \\
\hline Regulatory Quality (RQ) High = good quality & Worldwide Governance Indicators, The World Bank Group. \\
\hline $\begin{array}{l}\text { Ideological orientation of government }(\mathrm{IO})=\text { Economic Orientation } \\
\text { of Executive Branch of Government; } 1 \text { = right-wing executive }\end{array}$ & $\begin{array}{l}\text { Perspective Monde (Université de Sherbrooke) } \\
\text { Database of Political Institutions (DPI) }\end{array}$ \\
\hline $\begin{array}{l}\text { Systemic banking crisis }(\mathrm{BC})=1 \text { if country experienced banking } \\
\text { crisis that year }\end{array}$ & $\begin{array}{l}\text { Laeven. L and F. Valence (2008), Mario Dehove and Dominique } \\
\text { Plihon (2004), Gerard Caprio, Daniela Klingebiel, Luc Laeven } \\
\text { and Guillermo Noguera and Guillermo Noguera (2003) }\end{array}$ \\
\hline $\begin{array}{l}\text { Democratic accountability }(\mathrm{DA})=\text { Higher }=\text { government more } \\
\text { accountable to the people }\end{array}$ & International Country Risk \\
\hline $\begin{array}{l}\text { Political risk (PR): Measure of overall political risk; Lower = } \\
\text { greater political risk }\end{array}$ & International Country Risk Guide, PRS Group. \\
\hline $\begin{array}{l}\text { Political Stability (PS) = Measure of overall political Stability; } \\
\text { High = greater political Stability }\end{array}$ & Worldwide Governance Indicators, The World Bank Group. \\
\hline $\begin{array}{l}\text { Political instability }(\mathrm{PI})=\text { Measure of overall political instability; } \\
\text { Lower = greater political instability }\end{array}$ & Economist Intelligence Unit. \\
\hline $\begin{array}{l}\text { Democracy index }(\mathrm{DI})=\text { Measure of overall democracy; high = } \\
\text { greater democracy }\end{array}$ & $\begin{array}{l}\text { Economist Intelligence Unit. } \\
\text { Statistiques mondiales. }\end{array}$ \\
\hline Privatiaation $(\mathrm{P})=1$ after privatization and 0 before. & $\begin{array}{l}\text { Privatization Barometer } \\
\text { World Bank: Privatization Database. }\end{array}$ \\
\hline
\end{tabular}

\section{Empirical Results}

We conducted the binary logistic regressions with R-statistics software, version 2.11.1 to explain the government's decision to privatize a public bank (presence or absence of an event) as a function related to different economic, political and institutional variables using function glm with family $=$ binomial option. Next, we estimate a duration model that explicitly considers that this decision may vary with changes in the economic and political environment over time. 


\subsection{Results of Logistic Regressions for the MENA Countries}

The following table presents the results of logistic regression panel data. It examines the decisions of governments in the MENA region to privatize a public bank including all independent variables.

Table 2. Results of logistic regression

\begin{tabular}{ccccc}
\hline Variables & Coefficient & Standard deviation & z-value & Pr(>|t|) \\
\hline (Intercept) & $2.933 \mathrm{e}+01$ & $9.346 \mathrm{e}+00$ & 3.139 & $0.00170 * *$ \\
BC & $-1.702 \mathrm{e}+00$ & $1.155 \mathrm{e}+00$ & -1.473 & 0.14070 \\
MK & $-8.743 \mathrm{e}-06$ & $7.275 \mathrm{e}-06$ & -1.202 & 0.22945 \\
DC & NA & NA & NA & NA \\
GE & $-3.280 \mathrm{e}-02$ & $4.069 \mathrm{e}-02$ & -0.806 & 0.42022 \\
CI & $-9.064 \mathrm{e}-01$ & $4.628 \mathrm{e}-01$ & -1.959 & 0.05014. \\
DI & $9.255 \mathrm{e}-01$ & $5.608 \mathrm{e}-01$ & 1.650 & 0.09886. \\
PI & $-2.937 \mathrm{e}+00$ & $9.413 \mathrm{e}-01$ & -3.121 & $0.00180 * *$ \\
NPL & $7.478 \mathrm{e}-02$ & $5.361 \mathrm{e}-02$ & 1.395 & 0.16305 \\
IO & $-1.674 \mathrm{e}-01$ & $7.954 \mathrm{e}-01$ & -0.211 & 0.83327 \\
GDP & $-2.155 \mathrm{e}-07$ & $1.902 \mathrm{e}-07$ & -1.133 & 0.25722 \\
GNI & $3.925 \mathrm{e}-05$ & $2.702 \mathrm{e}-05$ & 1.453 & 0.14621 \\
RQ & $5.923 \mathrm{e}-02$ & $3.296 \mathrm{e}-02$ & 1.797 & 0.07233. \\
DA & $9.672 \mathrm{e}-01$ & $4.852 \mathrm{e}-01$ & 1.993 & $0.04622 *$ \\
PR & $-2.305 \mathrm{e}-01$ & $8.728 \mathrm{e}-02$ & -2.641 & $0.00826 * *$ \\
BD & $-9.514 \mathrm{e}-07$ & $1.662 \mathrm{e}-06$ & -0.572 & 0.56700 \\
GS & $-7.491 \mathrm{e}-01$ & $2.340 \mathrm{e}-0$ & -3.201 & $0.00137 * *$ \\
PS & $1.646 \mathrm{e}-02$ & $2.433 \mathrm{e}-02$ & 0.676 & 0.49887 \\
SPBS & $6.891 \mathrm{e}-08$ & $2.352 \mathrm{e}-07$ & 0.293 & 0.76957 \\
\hline F 02 & & &
\end{tabular}

Note. Signif. codes: 0 ‘***’ 0.001 ‘**’ 0.01 '*’ 0.05 '’0.1 ‘’1.

We note that from this table that summarizes the results of the study that there are some explanatory variables are statistically significant while others are not, and thereafter, they have no effect on our endogenous variable. To select the variables that have an impact on the government's decision to privatize a state-owned bank, we will treat statistically the collected data. To do this, we will use the automated stepwise logistic regression that eliminates automatically all non-significant independent variables in the model. To do this, we will use the automated stepwise logistic regression that eliminates automatically all non-significant independent variables in our model.

This regression had chosen among economic, political and institutional variables the smallest number of them that explain at best the variability of the government's decision to privatize a public bank. It enables us to keep only the variables that have a significant impact on our logistic regression, and then, it includes only in the model the variables that provide the best coefficients of determination. It gives us a model with the best performance, hence, the model has the lowest AIC (Akaike information criterion).

The initial model includes all explanatory variables related to political, economic and institutional factors and less good are then withdrawn until the withdrawal of a new variable significantly deteriorates the model. And then the procedure stops when there is no significant variable to select or insignificant variable to eliminate.

The AIC is a criterion for comparing models, often used to select the best model. The AIC criterion applies to estimated models by a maximum likelihood method. Our logistic regressions can enter in this context. The AIC is defined as: $\mathrm{AIC}=-2 \log \mathrm{L}+2 \mathrm{k}$, where $\mathrm{L}$ is the maximized likelihood and $\mathrm{k}$ the number of parameters in the model. With this criterion, the model deviance $-2 \log (\mathrm{L})$ is penalized by 2 times the number of parameters. AIC represents a compromise between the bias decreasing with the number of parameters, and parsimony, will describe the data with the smallest number of possible parameters. The rigor would like all compared models all derive from the same "comprehensive" Included in the list of the compared models. It is necessary to check that the conditions of use of the full model and the one selected are met. The best model is the one with the lowest AIC. 
Non-significant variables namely: ideological orientation of government (IO), government effectiveness (GS), debt crisis (DC), political stability (PS), le budget deficit (BD) and size of private banking sector (SPBS) are removed from the global model using the AIC. This procedure we bring to reduce the number of explanatory variables and combination of variables resulting in minimum AIC.

Table 3. Presents the results of stepwise logistic regression automated

\begin{tabular}{ccccc}
\hline Variables & Coefficient & Standard deviation & z-value & $\operatorname{Pr}(>|\mathbf{z}|)$ \\
\hline (Intercept) & $2.567 \mathrm{e}+01$ & $8.356 \mathrm{e}+00$ & 3.072 & $0.002127 * *$ \\
BC & $-1.596 \mathrm{e}+00$ & $1.108 \mathrm{e}+00$ & -1.440 & 0.149822 \\
MC & $-9.178 \mathrm{e}-06$ & $7.182 \mathrm{e}-06$ & -1.278 & 0.201268 \\
CI & $-1.017 \mathrm{e}+00$ & $4.387 \mathrm{e}-01$ & -2.318 & $0.020467 *$ \\
DI & $8.639 \mathrm{e}-01$ & $4.993 \mathrm{e}-01$ & 1.730 & 0.083588. \\
PS & $-2.731 \mathrm{e}+00$ & $8.285 \mathrm{e}-01$ & -3.297 & $0.000978 * * *$ \\
NPL & $8.894 \mathrm{e}-02$ & $4.987 \mathrm{e}-02$ & 1.783 & 0.074512. \\
GDP & $-9.503 \mathrm{e}-08$ & $4.663 \mathrm{e}-08$ & -2.038 & $0.041555 *$ \\
GNI & $4.179 \mathrm{e}-05$ & $2.570 \mathrm{e}-05$ & 1.626 & 0.103908 \\
RQ & $4.819 \mathrm{e}-02$ & $2.536 \mathrm{e}-02$ & 1.900 & 0.057385. \\
DA & $8.306 \mathrm{e}-01$ & $3.784 \mathrm{e}-01$ & 2.195 & $0.028163 *$ \\
PR & $-2.017 \mathrm{e}-01$ & $7.454 \mathrm{e}-02$ & -2.706 & $0.006808 * *$ \\
GS & $-6.548 \mathrm{e}-01$ & $2.088 \mathrm{e}-01$ & -3.135 & $0.001717 * *$ \\
\hline
\end{tabular}

Note. Signif. codes: 0 ‘***’0.001 ‘**’ 0.01 ‘*’ 0.05 ‘’0.1 ‘’ 1 .

Reading the table number 3 we find that all the estimated coefficients are statistically significant at the 0.001 , $0.01,0.05,0.1$ and 1 . If the standard deviation tends to zero, in this case there is no autocorrelation between the explanatory variable and the dependent variable, which increases its relevance on the endogenous variable.

Regarding the variables related to economic factors, it should be noted is that the value taken by the coefficient of Market Capitalization (MC) is negative, and thus has a negative impact on the government's decision to privatize a public bank, which means that more this variable is small, more the likelihood to privatize public banks by governments in the MENA region improves. The Systemic banking crisis (BC) variable negatively affects our endogenous variable, which means that less banking crises are triggered more governments are more likely to privatize public banks.

The non-performing loan variable (NPL) that we consider as a factor in measuring the quality of the banking sector is positively correlated with the government's probability to privatize a state-owned bank in the MENA countries. This variable negatively affects the performance of banks, because a high level of receivables involves important burdens on banks which negatively affect their performance. This result affirms the conclusions of Clarke and Cull (2002) who suggest that NPL affect positively and significantly the probability of public bank privatization.

Among the economic determinants of privatization, it retains the macroeconomic variable gross domestic product (GDP). The value taken by this coefficient is negative and significant, therefore negatively and totally affects our dependent variable. More GDP increases in MENA countries, more government's likelihood to privatize a state-owned bank decreases. As regards of gross national income per capita (GNI), it affects positively and significantly the probability of bank privatization.

Concerning the relationship between the government's decision to privatize a public bank and the different variables characterizing the political factors, the first thing that can be highlighted from the results is that democratic accountability (DA) positively affects our endogenous variable. The second point that can be seen is that the political risk (PR) and political instability (PI) negatively and significantly affect the probability of privatization, which means that more these two factors increases, more the probability of public bank privatization decreases.

The government stability (GS) has a negative and significant impact on the government's decision to privatize a public bank. But this result contradicts the conclusions of the work of many authors such as Clarke and Cull 
(2002), Bortolotti and Pinotti (2003) which reveal that the stability of the government has a positive and significant impact on the probability of privatization of public banks.

Turning to the variables that are related to institutional factors, it is reported that the regulatory Regulatory Quality (RQ), which captures perceptions of the ability of the government to formulate and implement sound policies and regulations that permit and promote private sector development, has a positive impact on our dependent variable. More the value of Regulatory Quality increases more the governments of countries in the MENA region tend to privatize public banks. The significance of this variable reflects that it has a total effect on the endogenous variable and it has a strong relevance on the latter because its standard deviation is close to zero.

Regarding the corruption index (CI), it negatively affects our endogenous variable. More corruption increases, more the probability of public bank privatization decreases. This result does not justify the assumption that the corruption and inefficiency are nonexistent (or less) in the private sector. Another exogenous variable related to institutional factors is the democracy index (DI) which is positively correlated with the dependent variable.

To express the degree of dependence and significant association between the different exogenous variables related to economic, political and institutional and the government's probability to privatize a public bank in MENA countries. We re-estimated our model another time with the odds ratio. In addition, odds ratios were calculated to facilitate the interpretation of the estimates (the variation in the probability of state-owned bank privatization) for an increase in a standard deviation of each independent variable. The odds ratio represents the relative variation of the instantaneous probability that a bank is privatized in year $t$, for a one-unit change in the independent variable. Our logistic regression with the odds ratio is estimated using Stata 11.The degree of predictability of various economic, political and institutional variables are presented in Table 4 .

Table 4. Results of automated stepwise logistic regression with the odds ratio

\begin{tabular}{ccccc}
\hline variables & Odds Ratio & Standard deviation & $\mathbf{z}$ & $\mathbf{P}>\mathbf{z}$ \\
\hline GDP & 0.9999999 & $4.66 \mathrm{e}-08$ & -2.04 & 0.042 \\
GNI & 1.000042 & 0.0000257 & 1.63 & 0.104 \\
MC & 0.9999908 & $7.18 \mathrm{e}-06$ & -1.28 & 0.201 \\
NPL & 1.093017 & 0.0545091 & 1.78 & 0.075 \\
BC & 0.2026593 & 0.2246215 & -1.44 & 0.150 \\
PR & 0.8173396 & 0.0609212 & -2.71 & 0.007 \\
GS & 0.5195579 & 0.1085067 & -3.14 & 0.002 \\
DA & 2.294732 & 0.8683561 & 2.20 & 0.028 \\
CI & 0.3617245 & 0.1587061 & -2.32 & 0.020 \\
RQ & 1.049368 & 0.0266093 & 1.90 & 0.057 \\
PI & 0.0651322 & .0539601 & -3.30 & 0.001 \\
DI & 2.372325 & 1.184453 & 1.73 & 0.084 \\
\hline
\end{tabular}

The privatization decision and the following three economic factors: gross national income per capita (GNI), gross domestic product (GDP) and market capitalization (MC), are linked together by an odds ratio equal to 1 . Given that odds ratio equal to unity corresponds to the absence of effect, this indicates that there is no associations between these three economic factors and the government's decision to privatize a public bank. In the MENA countries, governments do not seem to use the privatization of banks as instruments to extend the size and liquidity of stock markets.

The remaining two economic factors are the banking crisis (BC) and non-performing loans (NPL), this means that banking crises (BC) decrease the probability of bank privatization of $79.74 \%$. In this case, the government's decision to privatize a public bank has 5 times less likely to occur rather than do not to occur after banking crises. This indicates the existence of a weak association between this variable and the probability of bank privatization. While the second factor has an odds ratio upper to unit (1.093>1), an increase in the standard deviation of non-performing loans (NPL) of a unit increases the likelihood of public banks privatization of $9.3 \%$. Thereafter, the government's decision to privatize a public bank has 1,093 times more likely to occur. Overall, these results suggest that governments in the MENA region are more likely to privatize a public bank when the quality of the banking sector is bad. 
Regarding the political and institutional characteristics, our data indicate that the democracy index (DI), the regulatory quality (RQ) and the democratic accountability (DA) have an odds ratio greater than unity. This indicates the existence of a beneficial effect between these three factors and the likelihood of state-owned bank privatization in so far as the more the factor's odds-ratio is remote from the unit, the greater its effect on the probability of bank privatization is important.

However, in MENA countries, the democracy index (ID) and democratic accountability (DA), a significant determinant of state-owned bank privatization: a one-standard deviation in these two factor increases the likelihood of bank privatization respectively by $137.2 \%$ and $129.4 \%$ (the odds ratio are respectively 2.372 and 2.294). This is consistent with the hypothesis that a greater accountability to voters, by limiting the ability to extract political benefits from SOBs, should increase the likelihood of privatization.

On the contrary, a one-standard deviation in Political risk (PR) and Political instability (PI) decreases the likelihood of bank privatization respectively by $18.27 \%$ and $34.87 \%$ (the odds ratio are respectively 0.8173 and 0.6513). Also, same thing for Government Stability (GS) and Corruption Index (CI), a one-standard deviation in these two factor decreases the likelihood of bank privatization in the MENA countries respectively by $48.05 \%$ and $63.83 \%$ (the odds ratio are 0.5195 and 0.3617 ). The absence of a positive effect of the Government Stability (GS) on the public banks privatization and the existence of a negative relationship between them in MENA countries can be interpreted by a governmental stability which is characterized by dictatorship, tyranny, the impossibility of peaceful transfer of power, and the complete absence of any form of democracy, freedom and epidemics phenomena of corruption and nepotism.

Additionally, the regressions reveal significant relation between Regulatory Quality (RQ) and the probability of state-owned bank privatization: a one-standard deviation increase in the Regulatory Quality increases the likelihood of bank privatization by $4.9 \%$ (the odds ratio is 1.049 ). So there is a very weak association between this variable and the probability of bank privatization. More regulations that permit and promote private sector development are formulated and implemented by the governments of MENA countries, more their banks are likely to be privatized.

\subsection{Results of Logistic Regressions for the OECD Countries}

Table 5 presents the results of logistic regression that model a government's decision of OECD countries to privatize a state-owned bank including all independent variables.

Table 5. Results of logistic regression

\begin{tabular}{ccccc}
\hline Variables & Coefficient & Standard deviation & z-value & Pr $(>|\mathbf{t}|)$ \\
\hline Intercept $)$ & $-3.518 \mathrm{e}+00$ & $4.467 \mathrm{e}+00$ & -0.788 & 0.43087 \\
BC & $-1.656 \mathrm{e}-01$ & $3.227 \mathrm{e}-01$ & -0.513 & 0.60793 \\
MK & $7.402 \mathrm{e}-07$ & $2.877 \mathrm{e}-07$ & 2.573 & $0.01008 *$ \\
DC & $1.479 \mathrm{e}+00$ & $5.421 \mathrm{e}-01$ & 2.729 & $0.00635 * *$ \\
GE & $1.340 \mathrm{e}-02$ & $3.805 \mathrm{e}-02$ & 0.352 & 0.72479 \\
CI & $-7.386 \mathrm{e}-01$ & $2.458 \mathrm{e}-01$ & -3.005 & $0.00266 * *$ \\
DI & $2.706 \mathrm{e}-02$ & $4.193 \mathrm{e}-01$ & 0.065 & 0.94854 \\
PI & $-5.760 \mathrm{e}-04$ & $2.176 \mathrm{e}-01$ & -0.003 & 0.99789 \\
NPL & $-1.212 \mathrm{e}-02$ & $3.223 \mathrm{e}-02$ & -0.376 & 0.70676 \\
IO & $3.730 \mathrm{e}-01$ & $2.488 \mathrm{e}-01$ & 1.499 & 0.13383 \\
GDP & $6.083 \mathrm{e}-07$ & $4.867 \mathrm{e}-07$ & 1.250 & 0.21140 \\
GNI & $-1.060 \mathrm{e}-04$ & $2.015 \mathrm{e}-05$ & -5.262 & $1.42 \mathrm{e}-07 * * *$ \\
RQ & $9.122 \mathrm{e}-03$ & $3.303 \mathrm{e}-02$ & 0.276 & 0.78243 \\
DA & $9.725 \mathrm{e}-02$ & $8.386 \mathrm{e}-01$ & 0.116 & 0.90768 \\
BD & $8.429 \mathrm{e}-02$ & $5.715 \mathrm{e}-02$ & 1.475 & 0.14024 \\
PR & $-6.481 \mathrm{e}-08$ & $7.140 \mathrm{e}-07$ & -0.091 & 0.92768 \\
GS & $-1.444 \mathrm{e}-01$ & $1.432 \mathrm{e}-01$ & -1.009 & 0.31320 \\
PS & $1.592 \mathrm{e}-02$ & $1.577 \mathrm{e}-02$ & 1.009 & 0.31277 \\
SPBS & $-3.617 \mathrm{e}-09$ & $2.858 \mathrm{e}-09$ & -1.266 & 0.20566 \\
\hline
\end{tabular}

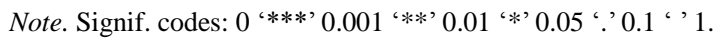


Table 6 presents our automated stepwise logistic regression results. The stepwise selection selected only as significant variables. The model to be used is the one with the lowest AIC.

Table 6. Results of automated stepwise logistic regression with the odds ratio

\begin{tabular}{ccccc}
\hline variables & Odds Ratio & Standard deviation & $\mathbf{z}$ & $\mathbf{P}>\mathbf{z}$ \\
\hline MC & 1.000001 & $2.07 \mathrm{e}-07$ & 3.69 & 0.000 \\
DC & 2.881388 & 1.220493 & 2.50 & 0.012 \\
CI & 0.5172597 & 0.0749018 & -4.55 & 0.000 \\
IO & 1.440005 & 0.3380709 & 1.55 & 0.120 \\
GNI & 0.9998952 & 0.0000188 & -5.59 & 0.000 \\
BD & 1.154839 & 0.0376433 & 4.42 & 0.000 \\
GS & 0.7395885 & 0.0678732 & -3.29 & 0.001 \\
SPBS & 1 & $1.12 \mathrm{e}-10$ & -0.99 & 0.320 \\
\hline
\end{tabular}

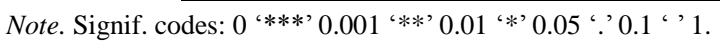

Regarding the economic characteristics, our data indicate that the budget deficit (BD) and the debt crisis (DC) are important factors in a government's decision of OECD countries to privatize a state-owned bank. Consistent with our predictions, there is a significant positive relation the debt crisis (DC) and the likelihood of public bank privatization. In fact, a one-standard deviation increase in debt crisis more than triples the likelihood of bank privatization (the odds ratio is 2.88).

However, the budget deficit (BD) is a significant determinant of state-owned bank privatization: a one-standard deviation increase in the deficit increases the likelihood of bank privatization by $15.48 \%$ (the odds ratio is 1.154).

In addition, the regressions reveal no relationship between the following three variables: Market Capitalization (MC), size of a nation's private banking sector (SPBS), Gross National Income (GNI) per capita and our dependent variable (the odds ratio is 1). Thereafter the absence of effect between them and the government's decision to privatize a public bank. In the OCED countries, size of the private banking sector and Gross National Income does not appear to affect the likelihood of state-owned bank privatization. The governments of OECD countries do not seem to use the privatization of banks as instruments to expand the size and liquidity of stock markets.

The regressions also support our hypotheses regarding the effect of political variables. Our primary political variable, ideological orientation of government (IO) is positive and significant: a one-standard deviation increase in the Ideological orientation increases the likelihood of bank privatization by $44 \%$ (the odds ratio is 1.44 ). Right-wing governments (conservative, Christian democratic or rightist parties) increase the likelihood of privatization of public banks in so far as the right-wing governments are supposed to promote less state involvement in the financial sector and promote the reduction of its intervention. on the other side, the left-wing governments (communist, socialist, or leftist parties) that exert more state control

Also, our secondary political variable, government Stability (GS) is an important factor in a government's decision to privatize state-owned bank, it is negative and significant: a one-standard deviation increase in the government Stability (GS) decreases the likelihood of bank privatization by $26.05 \%$ \% (the odds ratio is 0.7395 ). This can be explained by the fact that the inability of a government right to remain in power affects its ability to complete its privatization program declared.

\subsection{Determinants of the Timing of State-Owned Bank Privatization}

In addition to investigate the determinants of a country's decision to privatize a public bank, it is also important to identify the timing of this decision. To examine the factors impacting the decision to begin the privatization of state-owned banks, we will estimate a duration model with time-varying variable as covariates. We provide a specification of the Cox (1972) duration model. We report hazard ratios instead of coefficients because they are easier to interpret. Each ratio measures how much the hazard (i.e., the instantaneous risk of exiting) increases for a unit change in the covariate. Hazard ratios greater (less) than one imply that the covariate increases (decreases) 
the probability of exit.

Table 7 presents the results of duration models measuring determinants of the time until a country's first bank privatization estimated using the maximum partial likelihood (Cox, 1972) for the MENA region using stata 11 software.

Table 7. The results of the duration model for MENA countries

\begin{tabular}{ccccc}
\hline variables & Hazard Ratio & Standard deviation & $\mathbf{z}$ & $\mathbf{P}>\mathbf{z}$ \\
\hline PIB & 0.9999999 & $4.66 \mathrm{e}-08$ & -2.04 & 0.016 \\
PNBH & 1.000033 & 0.0000274 & 1.20 & 0.229 \\
CBR & 0.9999808 & $8.15 \mathrm{e}-06$ & -2.35 & 0.019 \\
NPL & 1.040409 & 0.0515766 & 0.80 & 0.424 \\
CB & 3.766088 & 4.276706 & 1.17 & 0.243 \\
RP & 0.8692037 & 0.0619993 & -1.97 & 0.049 \\
SG & 0.5030544 & 0.1137454 & -3.04 & 0.002 \\
RD & 1.971584 & 0.6934782 & 1.93 & 0.054 \\
IC & 0.7097452 & 0.2898755 & -0.84 & 0.401 \\
QR & 1.007344 & 0.0252374 & 0.29 & 0.770 \\
IP & 0.2780815 & 0.1725343 & -2.06 & 0.039 \\
ID & 1.403496 & 0.4038055 & 1.18 & 0.239 \\
\hline
\end{tabular}

We find that MENA countries whose banks are less efficient, and whose public officials are more accountable to the people privatize state-owned banks faster (more democratic accountability (DA) and whose governments are more likely to formulate and implement policies and regulations that promote private sector development (more regulatory quality $(\mathrm{QR})$ privatize public banks faster. We also find that countries with less political risk (PR), more government Stability (GS), less corruption (CI), less political instability (PI), more banking crises (BC) privatize state-owned banks faster.

For example, duration model shows that the hazard ratio associated with the political instability index (PI) is 0.27 . This suggests that a unit $(100 \%)$ increase in political instability index reduces the probability of bank privatization (in any given year) by $73 \%$. Similarly, a $10 \%$ increase in this variable would reduce the probability by $7.3 \%$.

Table 8 presents the results of duration models measuring determinants of the time until a country's first bank privatization estimated using the maximum partial likelihood (Cox, 1972) for the OECD countries using stata 11 software.

Table 8. The results of the duration model for OECD countries

\begin{tabular}{ccccc}
\hline variables & Hazard Ratio & Standard deviation & $\mathbf{z}$ & $\mathbf{P}>\mathbf{z}$ \\
\hline PNBH & 0.9998038 & 0.000015 & -13.06 & 0.000 \\
CBR & 1.000001 & $2.14 \mathrm{e}-07$ & 3.21 & 0.001 \\
TSBP & 1 & $1.48 \mathrm{e}-09$ & -0.45 & 0.651 \\
CD & 0.4316085 & 0.1624321 & -2.23 & 0.026 \\
OI & 1.961428 & 0.3936714 & 3.36 & 0.001 \\
DB & 1.224154 & .0331991 & 7.46 & 0.000 \\
SG & 0.8045078 & 0.0606198 & -2.89 & 0.004 \\
IC & 0.5158458 & 0.0623124 & -5.48 & 0.000 \\
\hline
\end{tabular}


We find that OECD countries whose governments belonging to right-wing parties, and more debt deficit (DF) privatize public banks faster. We also find that countries with less corruption (CI), less political instability (PI), less debt crises (BC) privatize state-owned banks faster.

For example, duration model shows that the hazard ratio associated with the debt crises (DC) is 1.96. This suggests that a unit (100\%) increase in debt crises variable increases the probability of bank privatization (in any given year) by $96 \%$.

\section{Conclusion}

This paper examines how political, institutional, and economic factors are related to a country's decision to privatize state-owned banks, and the various factors that affect whether and when governments decide to privatize a public bank.

Through the use of comprehensive data on privatization in the 38 OECD and MENA countries from 1988 to 2011. We find that the economic, political and institutional factors have a significant influence on the government's decision to privatize state-owned banks. The most important influences on the decision of a government to privatize a public bank in MENA countries relate to institutional political conditions, and the quality of the banking sector of the country. We also find that the privatization of public banks is more likely when banks are less efficient (are lower quality) and possess the highest non-performing loans (NPL).

Also, the data suggest that in the MENA region, the political characteristics are important in determining whether a country can privatize public banks. Specifically, countries that are politically unstable and more risky are less likely to privatize their state-owned banks. While countries that have greater accountability to voters and a good quality of regulation are more likely to privatize their state-owned banks. Again, countries that are more corrupt and have more stable governments are less likely to privatize public banks.

In contrast, political variables do not appear to be important determinants of privatization of public banks in OECD countries. Instead of these factors, it seems that other types of variables (e. g., economic variables such as the quality of the banking sector) influence the decision of the governments of OECD countries to privatize public banks.

These results are consistent with our assertion that different constraints on privatization are mandatory in all countries in MENA and OECD. Our results are robust to different estimation methods and alternative specifications of independent variables. Overall, this study contributes to the growing literature that examines how economic, political and institutional factors affecting capital markets and financial decisions.

\section{References}

Beck, T., George, C., Alberto, G., Philip, K., \& Patrick, W. (2001). New tools in comparative political economy: The database of political institutions. World Bank Economic Review, 15, 165-176. http://dx.doi.org/10.1093/wber/15.1.165

Berger, A. N., Clarke, G. R. G., Cull, R., Klapper, L., \& Udell, G. F. (2005). Corporate governance and bank performance: A joint analysis of the static, selection, and dynamic effects of domestic, foreign, and state $\begin{array}{llll}\text { ownership. Journal of Banking \& } & \text { Finance, 29(8-9), } 2179-2221 .\end{array}$ http://dx.doi.org/10.1016/j.jbankfin.2005.03.013

Boehmer, E., Robert, C. N., \& Jeffry, M. N. (2005). Bank privatization in developing and developed countries: Cross-sectional evidence on the impact of economic and political factors. Journal of Banking \& Finance, 29(8-9), 1981-2013. http://dx.doi.org/10.1016/j.jbankfin.2005.03.004

Bortolotti, B., \& Paolo, P. (2003). The political economy of privatization. Working paper, FEEM.

Bortolotti, B., Marcella, F., \& Domenico, S. (2001). Privatisation: Politics, institutions, and financial markets. Emerging Markets Reiew, 2(2), 109-136. http://dx.doi.org/10.1016/S1566-0141(01)00013-9

Bortolotti, B., Marcella, F., \& Domenico, S. (2003). Privatisation around the world: Evidence from panel data. Journal of Public Economics, 88(1-2), 305-332. http://dx.doi.org/10.1016/S0047-2727(02)00161-5

Clarke, G. R. G., \& Cull, R. (2002). Political and economic determinants of the likelihood of privatizing Argentine public banks. Journal of Law and Economics, 45(1), 165-197. http://dx.doi.org/10.1086/324653

Clarke, G. R. G., \& Robert, C. (2002). The political economy of privatization: An empirical analysis of bank privatization in Argentinaé. Working paper, World Bank.

Clarke, G. R. G., \& Robert, C. (2005). Bank privatization in Argentina: A model of political constraints and differential outcomes. Journal of Development Economics, 78(1), 133-155. 
http://dx.doi.org/10.1016/j.jdeveco.2004.06.010

Cox, D. (1972). Regression models and life-tables. Journal of the Royal Statistical Society, 34(2), 187-220.

Crivelli, E. (2013). Fiscal impact of privatization revisited: The role of tax revenues in transition economies. Economic Systems, 37(2), 217-232. http://dx.doi.org/10.1016/j.ecosys.2012.11.003

Donat, R., Philippe, L., Laurent, B., \& Patrice, A. (2010). A dynamic Bayesian network to represent discrete duration models. Neurocomputing, 73(4-3), 570-577. http://dx.doi.org/10.1016/j.neucom.2009.09.012

Jianga, C., Shujie, Y., \& Genfu, F. (2013). Bank ownership, privatization, and performance: Evidence from a transition country. Journal of Banking \& Finance, 37(9), 3364-3372. http://dx.doi.org/10.1016/j.jbankfin.2013.05.009

Maja, D. (2007). Privatization in Economic Theory. Panoeconomicus, 54(1), $103-118$. http://dx.doi.org/10.2298/PAN0701103D

Megginson, W. L., Robert, C. N., \& Matthias, V. R. (1994). The financial and operating performance of newly privatized firms: An international empirical analysis. Journal of Finance, 49(2), $403-452$. http://dx.doi.org/10.1111/j.1540-6261.1994.tb05147.x

Nicholas, A., \& Effrosyni, A. (2011). Bank efficiency: Evidence from a panel of European banks. Panoeconomicus, 58(3), 329-341. http://dx.doi.org/10.2298/PAN1103329A

OECD. (2009). Recent experience with privatisation in OECD countries. Privatisation in the 21st Century: Recent Experiences of OECD. Countries Report on Good Practices, January 2009.

Olson, D., \& Taisier, A. Z. (2011). Efficiency and bank profitability in MENA countries. Emerging Markets Review, 12(2), 94-110. http://dx.doi.org/10.1016/j.ememar.2011.02.003

Saffar, W. (2014). The political economy of share issue privatization: International evidence. Journal of Multinational Financial Management, 24, 1-18. http://dx.doi.org/10.1016/j.mulfin.2013.06.004

Sana, M., \& Isaac, O. (2014). Risk taking behavior of privatized banks. Journal of Corporate Finance, 29, 122-142. http://dx.doi.org/10.1016/j.jcorpfin.2014.07.007

Santiago, H., Christophe, H., \& Chahir, Z. (2014). Don't banks lend to Egypt's private sector? Economic Modelling, 33, 347-356.

Sergio, G., Lazzarini, A., Musacchio, R., \& Bandeira-de-Mello, R. M. (2015). What do state-owned development banks do? Evidence from BNDES 2002-09. World Development, 66, $237-253$. http://dx.doi.org/10.1016/j.worlddev.2014.08.016

Syed Qasim, S., \& Rizwan, J. (2014). Analysis of financial performance of private banks in Pakistan. Procedia-Social and Behavioral Sciences, 109(8), 1021-1025.

Thorsten, B., Cull, R., \& Jerome, A. (2005). Bank privatization and performance: Empirical evidence from Nigeria. Journal of Banking \& $\quad$ Finance, $29(8-9), \quad 235-2379$. http://dx.doi.org/10.1016/j.jbankfin.2005.03.018

Verbrugge, J., William, L. M., \& Owens, W. (2000). State ownership and the financial performance of privatized banks: An empirical analysis. In H. Rosenblum (Ed.), Proceedings of a policy research workshop at the World Bank (pp. 1-34). Federal Reserve Bank of Dallas.

Života, R. (2006). Privatization processes in banking: Motives and models. Panoeconomicus, 53(2), $191-221$. http://dx.doi.org/10.2298/PAN0602191R

\section{Copyrights}

Copyright for this article is retained by the author(s), with first publication rights granted to the journal.

This is an open-access article distributed under the terms and conditions of the Creative Commons Attribution license (http://creativecommons.org/licenses/by/3.0/). 